ISSN 2414-1143

Научный альманах стран Причерноморья. 2020. Том 22. № 2

DOI 10.23947/2414-1143-2020-22-2-92-99

UDC 379.85

\title{
"THE SILK ROUTE" AS A TOURIST RESOURSE
}

\author{
(c) Elena V. Dashkova, Elena B. Ivushkina
}

\author{
Chechen State University, Grozny, Chechen Republic, Russian Federation \\ science-almanac@mail.ru
}

The North Caucasus is one of the most beautiful and mysterious corners of the planet Earth. Amazing nature, majestic mountain peaks and ancient monuments attract numerous tourists. One of the important tasks of social and economic development of Russia is the creation of large-scale modern tourist zones or, as it is now said, destinations in the North Caucasus. The famous Silk Route, which played a unique role in the social, economic and cultural development of the regions of Eurasian space, was here centuries ago. The Silk Route (SR) is a grandiose trade route which connected the East and the West. It has caused the emergence of unique cities, historical monuments, customs and even states. In fact, it was a system of caravan roads leading from China to the countries in the Middle East and Europe. The Silk Route trails are resources for developing modern tourist routes. According to the World Tourism Organization (WTO) the Silk Route is the longest modern tourist route in the world. It covers Europe, Asia and Africa and links three oceans: Pacific, Indian and Atlantic. The Silk Route also passed through the southern territories of the Russian Federation and now Russia has become one of the active participants of the International Tourism Project "The Silk Route." In order to implement the international tourism project on this subject, it is necessary to develop new tourist routes based on the resources of the entities of the North Caucasus Federal District.

Key words: The Silk Route, culture, tourism, tourist route, tourist resources.

\section{[E.В. Дашкова, Е.Б. Ивушкина «Великий шёлковый путь» как туристский ресурс]}

Северный Кавказ - один из самых красивых и загадочных уголков планеты Земля. Изумительная природа, величественные горные вершины и древние памятники - всё это привлекает многочисленных туристов. Одной из важных задач социально-экономического развития России является создание на Северном Кавказе масштабных современных туристских зон, или, как теперь говорят, дестинаций. Много веков назад здесь пролегал знаменитый Великий шёлковый путь, который играл уникальную роль в социально-экономическом и культурном развитии регионов евразийского пространства. Великий шёлковый путь (ВШП) - грандиозный торговый маршрут, соединивший Восток и Запад и ставший причиной возникновения уникальных городов, исторических памятников, обычаев и даже государств. По сути, это была система караванных дорог, ведущих из Китая в страны Ближнего Востока и Европы. Тропы Великого шёлкового пути являются ресурсами для разработки современных туристских маршрутов. По данным Всемирной туристской организации (ЮНВТО), это самый протяжённый современный туристский маршрут в мире. Он охватывает Европу, Азию и Африку и связывает три океана: Тихий, Индийский и Атлантический. Великий шёлковый путь проходил и по южным территориям Российской Федерации и теперь Россия стала одним из активных участников Международного туристского проекта «Великий шёлковый путь». Для реализации международного туристского проекта по этой тематике, необходимо разработать новые туристские маршруты на основе ресурсов субъектов Северного-Кавказского федерального округа.

Ключевые слова: Великий Шёлковый путь, культура, туризм, туристский маршрут, туристские ресурсы.

Elena V. Dashkova - Ph.D. in Philosophy, Associate Professor, Chechen State University, Grozny, Chechen Republic, Russian Federation.

Elena B. Ivushkina - Ph.D. (Advanced Doctorate) in Philosophy, Professor, Chechen State University, Grozny, Chechen Republic, Russian Federation. 
Дашкова Елена Валерьевна - кандидат фрилософрких наук, дочент, Чеченский государственный университет, г. Грозный, Чеченская республика, Российская Федерация.

Ивушкина Елена Борисовна - доктор фолософских наук, профессор, Чеченский государственный университет, г. Грозный, Чеченская республика, Российская Федерация.

The Silk Route covered significant areas from China to Europe. This territory has preserved a unique cultural heritage, which can become the basis of cultural tourism. At the present stage, the Silk Route is a resource for the development of a cross-border tourist route. According to the World Tourism Organization (WTO) it is the longest tourist route in the world. It covers Asia, North Africa, Southern Europe and links three oceans: Pacific, Indian and Atlantic. "The route passes through the territory of countries with an area of 55.4 million $\mathrm{km} 2$ or $43 \%$ of the land area of the globe, the population is 4.7 billion people $(66.9 \%$ of the total population of the planet), the total GDP is 27.4 trillion dollars (53.6\%) [3]."

The Silk Route project will be implemented by two international organizations UNESCO and WTO which have special powers. UNESCO will operate under the slogan "The Silk Route the Path of Dialogue, Diversity and Development." In 1988-1997 comprehensive international studies "The Silk Route is Towards Dialogue" were carried out under the auspices of UNESCO.

In the first quarter of the 21st century, with the development of digitalization of the communication process, the online platform "The Silk Route" was created. "The promotion of cultural diversity and the assistance of intercultural dialogue are the most effective ways of building bridges between peoples, which contributes to peace, and it is for this purpose UNESCO launched a new online platform "The Silk Route" in accordance with the proclamation of the International Decade for the Rapprochement of Cultures (2013-2022) [4].

The online platform "The Silk Route" provides information on the traditions of peoples participating in the project of revival of the Silk Route, assists in understanding the importance of such an issue as the rapprochement of cultures in countries traditionally located in the territories where the Silk Route passed in ancient times. There are more than 40 modern countries on the territory of the Silk Route (Figure 1).

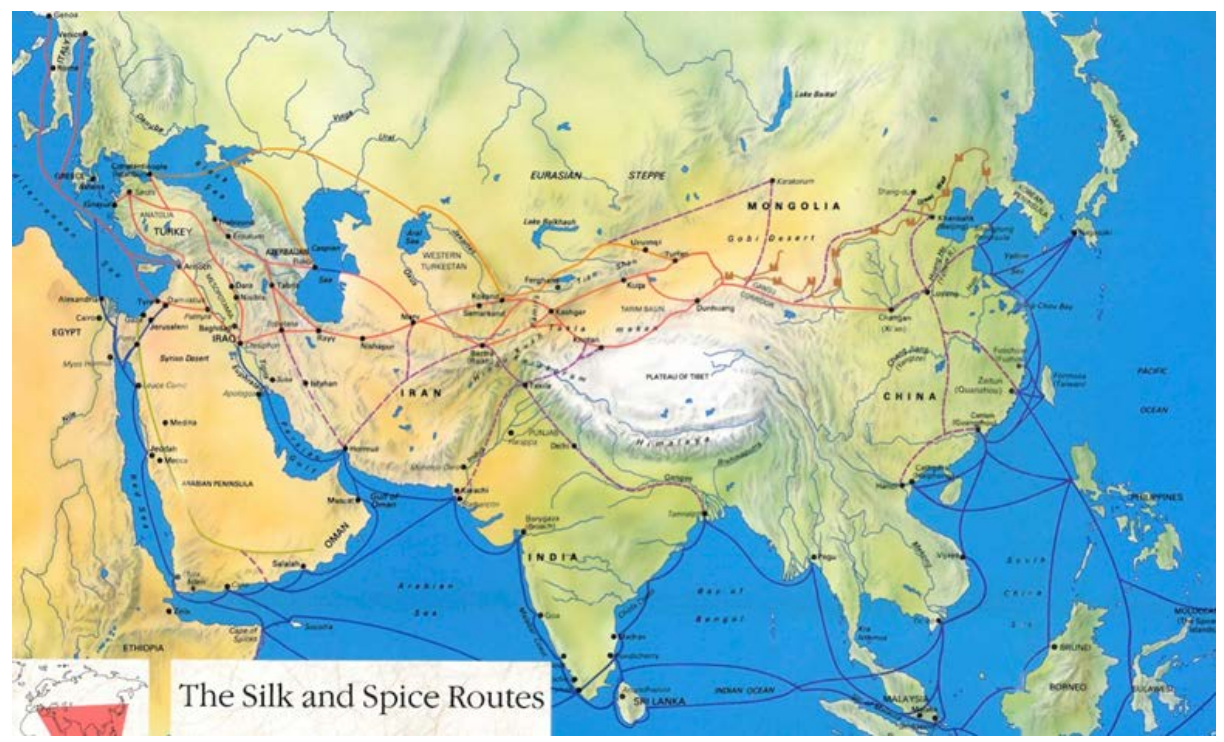

Figure 1. The Silk Route 
An interactive map of the Silk Route has been developed on the online platform. It identifies centers where scientific conferences and festivals are held, World Cultural and Natural Heritage sites, tangible and intangible cultural heritage sites, centers of useful arts, etc.

The Russian Federation is represented by only four cultural and historical sites on the interactive map. These are the Golden Mountains of Altai, Uvs Lake Basin, the natural park "Volga-Akhtubinsky floodplain" (Volgograd region) and the collection of maps of the Russian Empire of the 18th century (Moscow). This does not correspond to the entire cultural and historical heritage of Russia, which is connected with the Silk Route. Based on this situation, the attention to the participation in the implementation of the international project "The Silk Route" has increased in Russia. The Activity Plan of the Ministry of Culture of the Russian Federation included paragraph 5.9: "...To form interregional historical and cultural tourist routes by involving in the tourist circulation monuments of history, culture, archaeology - "The Silk Route..." [2, p. 12].

In 2015 the Russian Federation took an active part in the Seventh International Meeting of the World Tourism Organization (WTO) of the United Nations on tourism on the Silk Route. Russia, together with China, Kazakhstan, Oman, Azerbaijan and other participating countries, has entered the international program for the development of the Silk Route, the main goal of which is to ensure the sustainable development of tourism in the territory of the countries where the Silk Route passed. Sustainable development of tourism is possible only with the use of the potential of cultural tourism in the territory on the principles of preservation of the cultural, historical, natural and intangible heritage of the peoples of these countries.

The Russian Federation, like other UNESCO member States on the Silk Route, joined the Committee of the International Network "The Silk Route." "The adopted joint declaration stressed the importance of the Silk Route in solving the problems of rapprochement of different peoples, strengthening of intercultural dialogue and mutual understanding [5]."

The theme of the Silk Route is complex, multifaceted. Let's focus on some aspects of it.

Geopolitical aspects. The trails of the Silk Route "were an arterial road on which religious teachings, works of art, science, languages and technical achievements were exchanged. A lot of elements of civilization came with commercial goods which traders carried from country to country." [6, p. 208]

The new project of the Silk Route is more often presented under the slogan "One belt is one way!". It covers more than 3 billion people. Industrial outputs can reach 21 trillion dollars within its borders. One of the main tools for promoting this project is "The Silk Route Development Fund", established in 2014, for which China has allocated $\$ 40$ billion. However, the project of revival of the Silk Route is geopolitical because it is aimed at mutually beneficial international cooperation and formation of a balanced and comprehensive model of development of modern society. Implementation of the project of the new Silk Route will provide impetus to the development of tourism. The inflow of foreign investments in the tourism industry will increase, innovative processes in reducing various barriers will intensify, etc.

Geographical aspects. In terms of geography, the features of the project "The Silk Route the Path of Dialogue, Diversity and Development" are revealed through the diversity and concentration of cultural and historical objects (although this feature is characterized by uneven coverage of very large territories). Ways of the Silk Route are laid down in areas where tourist resources of natural and man-made origin are concentrated. Cultural tourism resources are concentrated in countries such as the People's Republic of China, the Republics of Uzbekistan, Kazakhstan, Azerbaijan, the Russian Federation and others. Therefore, the rich potential of the 
various resources found on the overland and sea trails of the Silk Route seems to be a strong aspect of the project "The Silk Route - the Path of Dialogue, Diversity and Development."

Economic aspects. The trails of the Silk Route pass through the territory of countries with huge socio-economic potential for tourism development. In the East there are two of the five BRIC countries with the world's largest economies in terms of GDP parity: China is on the 1st place in the world, India is on the 3rd.

Russia as a participant of the project "The Silk Route - the Path of Dialogue, Diversity and Development" has unique cultural and historical resources. Participation in this international project contributes to the solution of the tasks set out in the Strategy for the Development of Tourism in the Russian Federation for the period up to 2035:

" - Usage of an integrated approach to tourism development that takes into account economic, social, cultural, environmental and other aspects of tourism development;

- Ensuring intercultural communication and international cooperation in tourism development;

- Ensuring the necessary diversity through the formation of a tourist product, taking into account ethnic, religious and other characteristics of the population" [7, p. 13].

The tourism industry has now become a world-wide industry. It is on the 3rd place among the largest export sectors of the economy in terms of income, behind only the oil and automotive industries. Therefore, the economic dimension is given considerable attention.

The North Caucasus is one of the most beautiful corners of the planet Earth. Majestic pristine nature, mountain climate, interesting cultural and historical heritage, all this attracts numerous tourists. The history of the North Caucasus intersects with the Silk Route. Therefore, the phenomenon of the Silk Route can contribute to the sustainable development of tourism in the republics of the North Caucasus. Let us consider in more detail the resource component of the project "The Silk Route - the Path of Dialogue, Diversity and Development" in the territory of the current Chechen Republic.

The Silk Route is known in the world history from the 5th century BC. From the 2nd century BC until the end of the 17th century it was one of the most famous and the longest trade routes. The main historical significance of the Silk Route lies primarily in the fact that the trails of the Silk Route contributed to the cultural exchange among various peoples of the world. They also contributed to the destruction of the isolation of the Vainakh peoples who inhabited the territories of modern Chechnya and Ingushetia. The Silk Route started with the territory of China and, crossing vast territories, went to Europe by two branches. First-direction trails exited China through India, Afghanistan, further down the south side of the Khazar Sea (now, the Caspian Sea), crossed Iran, Byzantium, and reached Southern Europe. The second direction trails passed through Central Asia, on the northern shore of the Khazar Sea, then turned south and on the coasts of Terek of Kuban went to Crimea and Europe.

At different historical periods traffic on these branches was different in intensity. For example, after the Islamic Caliphate had seized Iran with Transcaucasia and after the Caliphate's years-long wars with Byzantium, the southern trails of the Silk Route merged with the northern trails and passed through the entire North Caucasus. This occurred during the heyday of the Khazar Kaganate (7th-10th centuries).

And although the name "The Silk Route" appeared only in the 19th century, one of the main civilizational achievements of this trade route was the spread not only of silk, but also of silkworm. Along the main trails of the Silk Route new centers for the production and sale of silk appears. The example of such centers is Central Asia (Sogdia), Iran and Byzantium. In the North Caucasus, including Chechnya, artifacts related to silk production are being found to this 
day. The names of settlements, such as the village of Shelkovskaya, also speak of the spread of this craft until the 19th century. "Analysis of silk fabrics found in North Caucasus graves (in archaeological excavations) gives an idea of the ratio of importing countries in this international trade: about 50\% of Sogdian-made silk tissues, 25\% Byzantine, 20\% Chinese and 5\% Persian. According to the information we received, Central Asian silk fabrics dominated both among merchants and among buyers. The North Caucasus, including Chechnya, in the 6th-14th centuries were connected to the outside world by four or five northern branches of the Silk Route. The first was from Iran to Coastal Dagestan, then to Chechnya and further to Byzantium, Rus and Europe. The second was from Iran to Georgia, then to the Darial Gorge, to Chechnya and further. The third was from Byzantium to the Black Sea coast, then to Chechnya and further. The fourth was from Central Asia to lower Volga, then to Terek (Chechnya) and further [8]."

Since Chechnya occupied a strategic position in the North Caucasus, there was another trail along the Argun Gorge to Georgia, Iran and Byzantium. During excavations elements of various goods from distant countries are found in these territories, and Vainakh merchants were known in many countries. Going on the trails of the Silk Route through the territory of modern Chechnya contributed to the economic development of Vainakh society: the development of trading relations, the high level of craft production led to the emergence of large medieval settlements. Due to the weakening of the Khazar State in the 10th century, the Alan State is formed within the borders of Chechnya, Ingushetia, North Ossetia, Kabardino-Balkaria, Karachay-Cherkessia and Pyatigoria. The high level of cultural development of the Nakh people in the early Middle Ages is evidenced by the fact that more than 150 only large settlements and towns of the early Middle Ages were discovered here. "Numerous representatives of Caucasian scientists argue that the Chechen people (Nakh people, Nakhchmatian people) are the indigenous, aboriginal population of the North Caucasus, who had very close trade and cultural ties with West Asia and Transcaucasia" [1, p. 111].

The largest Nakhian settlements and towns are Alhan-Kalinsky, Shelkov and Gudermes. These settlements were densely populated, and the economic activities of the population were diverse: cattle farming, pottery, fishing and others.

In the 13th century the Mongolian nomads did not spare Nakh towns and the record mentions the one-and-a-half-month siege of the city of Magas (1238). This difficult period is the persistent struggle of Nach people against Mongolo-Tatar invaders.

In the 1940s of the 13th century Alania broke up into separate feudal ownerships. At the same time, the State of Simsir, located in the territory of present-day Chechnya and Ingushetia, is mentioned. In 1395 this State was destroyed by the new conqueror Timur, with whom the ruler of Simsir Gayurhan fought. Nevertheless, in written sources and testimonies of travelers, it is noted that contrary to the military events khans of the Golden Horde encouraged international transit trade, including the caravan trade of silk, herds of horses and other goods, as the trade generated great income to the Golden Horde treasury.

Therefore, it can be considered that at that time the Silk Route continued to play an important role in the economic and cultural life of the region.

In the second half of the 16th century, the peoples of the North Caucasus established friendly ties with Moscow Rus and the Cossacks began to settle on the coast of Terek. In the 17th-18th centuries Russia attempted to revive silkworm and silk production on the left bank of the river Terek. To this end, silky worms were brought here from Iran and specialists were invited from Armenia and Georgia. These events are connected with the appearance of the names of the villages Shelkovskaya and Shelkozavodskaya in the current Shelkovsky district on 
the territory of Chechnya. This occupation generated income for the Cossacks and this activity was carried out by the Chechen people living on the right bank of the river Terek. Peter the Great was very interested in the revival of silk production and repeatedly wrote about it to the commander of the fortress Terki and to the Astrakhan voivode. The Chechen people, who lived in the fortresses of Terki and Kizlyar, were intermediaries in the delivery of raw silk and silk material from Chechnya to Astrakhan. Thus, Chechnya has the historical right to participate in the project "The Silk Route - the Path of Dialogue, Diversity and Development," as it passed through the territory of Chechnya by several branches and had been playing an important role in the life of Chechen society for many centuries.

At the present stage, the leadership of the Chechen Republic is betting on the development of tourism. One type of tourism that has a powerful resource base is cultural tourism. In order to attract tourists to the Chechen Republic, such tourist objects as open-air museums, architectural and ethnographic museums stylized as medieval Chechen settlements are being created. The complex called "Shira-Yurt" is located in the Shalinsky district, near the village of Germenchuk. In the mountainous area, in the area of the villages of Shata and Borza there is construction of the ethnic park "Dailam." On the territory of the ethnic park there will be a prototype of the Chechen aul with a fortress wall, towers, a forge, a bakery and other elements of traditional mountain rural life. A unique complex "Shira bena yurt" has been created in Kolay-Yurt district, where techniques of historical reconstruction are actively used during animation programs for tourists. This can contribute to the development of new tourist routes within the framework of the project "The Silk Route - the Path of Dialogue, Diversity and Development."

\section{Лumepamypa}

1. Гапуров Ш.А. «Откуда есть пошла земля Чеченская» (Некоторые вопросы этнической истории чеченцев) / Ш.А. Гапуров, Х.С. Умхаев // «Кавказский мир: проблемы образования, языка, литературы, истории и религии»: материалы международной научно-практической конференции, посвященной 80-летию Чеченского государственного университете, 25-26 сентября 2018 г., г. Грозный. Махачкала: АЛЕФ, 2018. С.108-115

2. Историко-культурное наследие Великого Шёлкового пути и продвижение туристской дестинации на Северном Кавказе: материалы III международной научнопрактической конференции (Ставрополь 5-7 октября 2017) // под редакцией В.С. Белозерова, И.В. Крючкова. Ставрополь: Изд-во СКФУ, 2017.

3. О Великом шёлковом пути: Официальный сайт «Организация Объединенных Наций по вопросам образования, науки и культуры (UNESCO)». URL: http:// https://ru.unesco.org/silkroad/, свободный (дата обращения 30.03.2020).

4. Онлайн-платформа ЮНЕСКО «Шёлковый путь»: Официальный сайт «Организация Объединенных Наций по вопросам образования, науки и культуры (UNESCO)». URL: http://https://ru.unesco.org/sillkroad/, свободный (дата обращения 30.03.2020)

5. Официальный сайт «Организация Объединенных Наций по вопросам образования, науки и культуры (UNESCO)». URL: https://ru.unesco.org/silkroad/knowledge-banksearch?s=\&field_route=All\&field_country_entity=176\&field_themes=All\&field_author, свободный (дата обращения 31.03.2020) 
6. Погодин С.Н. Интеграционный проект: Великий Шёлковый путь (к истории создания) / С.Н. Погодин, Чжоу Цзюнь // Управленческое консультирование. 2017. №1. С.205209.

7. Стратегия развития туризма в Российской Федерации на период до 2035 года: Официальный сайт Правительства России. Раздел «Документы». URL: http://government.ru/docs/37906/, свободный (дата обращения 31.03.2020).

8. Хизриев Х.А. Чечня на перекрестке Великого шёлкового пути («Вести республики»): Информационное агентство «ГРОЗНЫЙ ИНФОРМ». URL: http://www.groznyinform.ru/news/review/29121/, свободный (дата обращения 04.04.2020).

\section{References}

1. Gapurov Sh.A. "Otkuda est poshla zemlia Chechenskaia" (Nekotorye voprosy etnicheskoi istorii chechentsev). Sh.A. Gapurov, Kh.S. Umkhaev. "Kavkazskii mir: problemy obrazovaniia, iazyka, literatury, istorii i religii": materialy mezhdunarodnoi nauchnoprakticheskoi konferentsii, posviashchennoi 80-letiiu Chechenskogo gosudarstvennogo universitete, 25-26 sentiabria 2018 g., g. Groznyi. Makhachkala: ALEF ["Where is the earth Chechen from" (Some questions of ethnic history of the Chechens). Sh.A. Gapurov, H.S. Umkhayev. "The Caucasian world: problems of education, language, literature, history and religion": materials of the international scientific and practical conference devoted to the 80 anniversary of the Chechen State University, September 25-26, 2018, Grozny. Makhachkala: ALEF], 2018. pp. 108-115.

2. Istoriko-kulturnoe nasledie Velikogo Shelkovogo puti i prodvizhenie turistskoi destinatsii na Severnom Kavkaze: materialy III mezhdunarodnoi nauchno-prakticheskoi konferentsii (Stavropol 5-7 oktiabria 2017), pod redaktsiei V.S. Belozerova, I.V. Kriuchkova. Stavropol: Izd-vo SKFU [Historical and cultural heritage of the Silk Route and promotion of tourist destination in the North Caucasus: materials of the III International Scientific and Practical Conference (Stavropol, 5-7 October 2017), under the editorship of V.S. Belozerov, I.V. Kriuchkov. Stavropol: SCFU], 2017.

3. O Velikom shelkovom puti: Ofitsialnyi sait "Organizatsiia Obedinennykh Natsii po voprosam obrazovaniia, nauki i kultury [About the Silk Route: Official website "United Nations Educational, Scientific and Cultural Organization (UNESCO)."]. Available at: https://ru.unesco.org/sillkroad/, free (accessed 30 March 2020).

4. Onlain-platforma UNESKO "Shelkovyi put": Ofitsialnyi sait "Organizatsiia Obedinennykh Natsii po voprosam obrazovaniia, nauki i kultury [UNESCO online platform "The Silk Route": Official website United Nations Educational, Scientific and Cultural Organization (UNESCO)]. Available at: http://https://ru.unesco.org/silkroad/, free (accessed 30 March 2020).

5. Ofitsialnyi sait "Organizatsiia Obedinennykh Natsii po voprosam obrazovaniia, nauki i kultury (UNESCO)'. [Official website "United Nations Educational, Scientific and Cultural Organization (UNESCO)."]. Available at: https://ru.unesco.org/silkroad/knowledge-banksearch? s=\&field_route=All\&field_country_entity=176\&field_themes=All\&field_author, free (accessed 31 March 2020).

6. Pogodin S.N. Integratsionnyi proekt: Velikii Shelkovyi put (k istorii sozdaniia). S.N. Pogodin, Chzhou Tsziun. Upravlencheskoe konsultirovanie. [Integration Project: The Silk Route (to the history of creation). S.N. Pogodin, Chzhou Tsziun. Management Consulting.]. 2017. No.1. pp. 205-209. 
7. Strategiia razvitiia turizma v Rossiiskoi Federatsii na period do 2035 goda: Ofitsialnyi sait Pravitelstva Rossii. Razdel "Dokumenty". [Strategy of tourism development in the Russian Federation for the period up to 2035: Official website of the Government of Russia. Section "Documents".]. Available at: http://government.ru/docs/37906/, free (accessed 31 March 2020).

8. Khizriev Kh.A. Chechnia na perekrestke Velikogo shelkovogo puti ("Vesti respubliki"): Informatsionnoe agentstvo "GROZNYI INFORM". [Chechnya is at the intersection of the Silk Route ("News of the Republic"): News agency "GROZNY INFORM."]. Available at: http://www.grozny-inform.ru/news/review/29121/, free (accessed 4 April 2020). 